\title{
Collisional emplacement history of the Naga-Andaman ophiolites and the position of the eastern Indian suture
}

\author{
Subhrangsu K Acharyya \\ Department of Geological Sciences, Jadavpur University, Kolkata 700032, INDIA
}

For correspondence, E-mail: skacharyya@yahoo.com

Late Mesozoic to early Eocene ophiolites and associated rocks occur in two parallel north-south trending belts along the eastern margin of the Indian plate (Anon 1977, 1986). The presence of glaucophane and jadeite bearing schists in the ophiolite mélange indicate involvement of subduction process. The eastern belt passes through central Myanmar, Sumatra and Java, and broadly coincides with a zone of gravity high resulting from steeply dipping mafic-ultramafic rocks. The ophiolitic rocks in the eastern belt are often intruded by the Mid Cretaceous and younger plutons of the Central-Burmese magmatic arc and are also covered by younger rocks to the south. Geological details are less known from this belt. It possibly denotes the loci of the collision zone developed along the eastern and western margins of a Central Burmese micro-continent during its respective sutering with the Sino-Burman and the Indian blocks (Figure 1). In contrast, the western belt, which passes through the IndoBurmese Range (Nagaland and Manipur states, India, Chin Hills and Arakan Yoma in Myanmar) and Andaman Island Arc (India), similar assemblage of ophiolites and associated rocks occur as rootless, subhorizontal bodies tectonically overriding the Eocene-Oligocene flyschoid sequence. This belt is flanked to the east by a negative gravity anomaly zone. These ophiolitic rocks are inferred to represent a westward propagated nappe from the eastern belt, which represents the suture during the late Oligocene terminal collision of the Indian and the Burmese continents (Sengupta et al. 1990).

In the northern parts of Central Burmese magmatic arc, adjacent jade mine belt and upper defiles of the Irrawadi river, narrow belts of mafic-ultramafic rocks and cherts, and metamorphic rocks like mica schist, graphitic schist, kyanite schist and Triassic turbidites occur in complex structural association. These rocks are intruded by mid Cretaceous granodiorite-tonalite plutons and unconformably overlain by shallow marine Albian limestone (Anon 1986, Mitchell 1993). Early Eocene debris flow is also recorded with serpentinite and other clasts. These ophiolites and Triassic turbidites were possibly accreted at a west dipping subduction zone due to closure of a small ocean basin separating a Central Burma microcontinent and the Sino-Burmese continent (Figure 1a-b). The plutons intruding the accretionary prism were possibly generated by an east dipping subduction beneath the collided Burmese continents (Figure 1b).

Similar assemblage of ophiolitic rocks, and clastics with ophiolitic and metamorphic rocks are recorded from the Naga Hills and Andaman Islands of the western belt (Acharyya et al. 1990, Acharyya 1997). Continent derived Triassic turbidites override Mt. Victoria basement dome and in turn are overridden by the ophiolites in the eastern parts of the Chin Hills (Mitchell 1993), whereas Triassic elements occur within the Eocene olistostromes in Andaman (Acharyya 1997). Eocene conglomerate beds with granodiorite and dacite clasts overlie the ophiolites and Albian limestone along the eastern margin of the Chin Hills (Mitchell 1993). In Naga Hills, the accreted ophiolites and their cover are overthrust by metamorphic rocks comprising micaschists, garnet-micaschists, gneisses, which at places are unconformably overlain by mid Cretaceous continental arkosic quartzite and limestone. Smaller bodies of metamorphic rocks occur in the ophiolites from Andaman (Acharyya et al. 1990).

The mid Eocene age of ophiolite-derived and plagioclase bearing clastic rocks occurring in places as unconformable cover on the western belt ophiolite slices, especially from Naga Hills and at places in Andaman Islands, marks the minimum accretion age of these ophiolites (Figure 1d-e). The olistostromal units juxtaposed to and tectonically underlying the ophiolites is a trench deposit containing olistoliths of various sizes and ages. The youngest olistoliths of mid Eocene age represent the age of trench sediments. The age of these two contrasting sedimentary facies marks the beginning of a second phase of subductionrelated ophiolite accretion just prior to mid Eocene (Acharyya et al. 1990). Several Eocene dioritic intrusives and related volcanic rocks from the Sino-Burmese range east of inferred suture confirm location of this subduction zone. The chemistry of basalts, associated shallow marine limestone, and the fauna indicate that Maastrichtian and Palaeocene seamounts were important constituents of the subducting ocean crust (Sengupta et al. 1990). Clipped off parts of seamounts together with slices from ocean floor were accreted at the leading margin of the overriding Sino-Burmese continent to the east (Figure 1d-e). Continued subduction brought the Indian and the SinoBurmese blocks closer to each other. During this period, which spanned parts of the Eocene and the Oligocene, uninterrupted flysch sediments were deposited on the margin of the Indian continental block towards the west. With closure of the ocean, the Indian and Sino-Burmese continental blocks collided along a suture, which was located along the eastern belt ophiolites; the late Oligocene pronounced unconformity marks the time of terminal collision (Acharyya et al. 1990). Gently dipping ophiolitic slices, their cover, together with the metamorphic basement of the overriding continent and olistostromal trench rocks, were thrust westward from the suture as nappes (Figure lf-g). Although the components of both ophiolite belts are similar, the presence of late Cretaceous - early Eocene ophiolites has not yet been established from the eastern belt. These rocks may be tectonically concealed or truncated. The floor sediments, the nappe rocks as well as the younger Neogene sediments in the western belt were subsequently co-folded. Mitchell (1993), on the other hand, postulated that the eastern belt ophiolites were overthrust from the Indo-Burmese Range eastward, which lacks factual support.

Ophiolite occurrences in the Andaman Islands, belonging to the western belt, are generally linked with active subduction west of the island arc. The accreted ophiolites from this belt, however, already existed as tectonised on-land features during mid Eocene and thus much before the initiation of late Miocene subduction and opening of the Andaman Sea (cf. Curray et al. 1982). It is inferred that in the north, the collision occurred between the Sino-Burmese and the main Indian continent 
(Figure 1d-f), whereas, in the south, it occurred between the SinoBurmese and a small continental fragment that was separated from the main Indian continent by parts of the Indian Ocean (Figure 1e-g). As a result, a new subduction regime and active Andaman-Java trench developed along the western margin of continental fragment in the southern sector after the Late Oligocene terminal collision (Figure 1i).

\section{References}

Acharyya SK. 1997. Stratigraphy and tectonic history reconstruction of the Indo-Burma-Andaman mobile belt. Ind J Geol 69: 211-234

Acharyya SK, KK Ray and S Sengupta. 1990. Tectonics of the ophiolite belt from Naga Hills and Andaman Islands, India. Proc Ind Acad Sci (Earth Planet Sci) 99: 187-199

Anon. 1977. Geological map of the Socialistic Republic of the Union of Burma, 1:1M. Burma: Earth Sciences Research Division, Govt. of Burma.

Anon. 1986. Geology of Nagaland ophiolite. Geol Surv Ind Mem 119: $113 \mathrm{p}$ Curray JR, FJ Emmel, DG Moore and RW Raitt. 1982. Structure, tectonics and geological history of the northeast Indian Ocean. In: Nairn AEM and FG Stehli (eds), The Ocean Basins and Margins, Vol 6: The Indian Ocean. New York: Plenum Press. p 399-450

Mitchell AHG. 1993. Cretaceous-Cenozoic tectonic events in the western Myanmar (Burma) - Assam region. J Geol Soc Lond 150: 1089-102

Sengupta S, KK Ray, SK Acharyya and JB deSmeth. 1990. Nature of ophiolite occurrences along the eastern margin of the Indian plate and their tectonic significance. Geology 18: 439-442
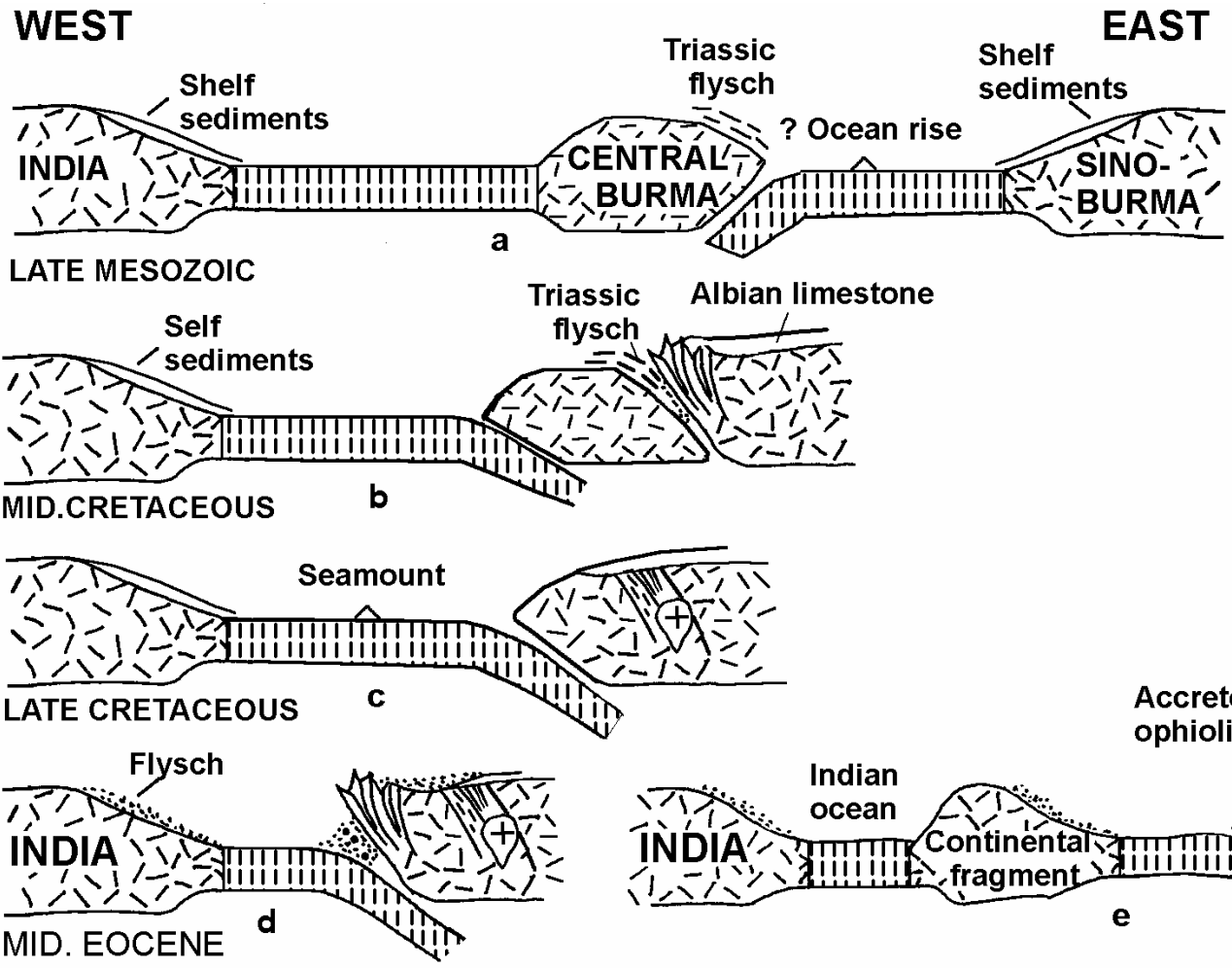

Nagaland-Manipur setting

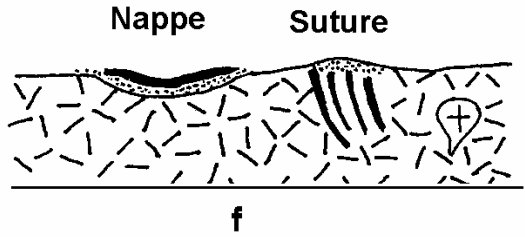

LATE OLIGOCENE

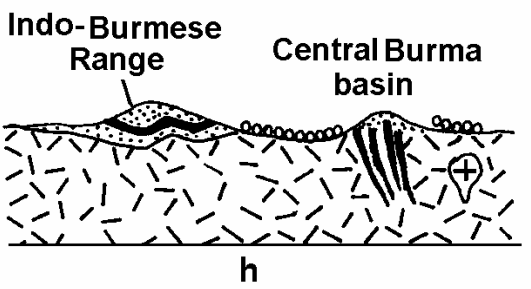

LATE MIOCENE

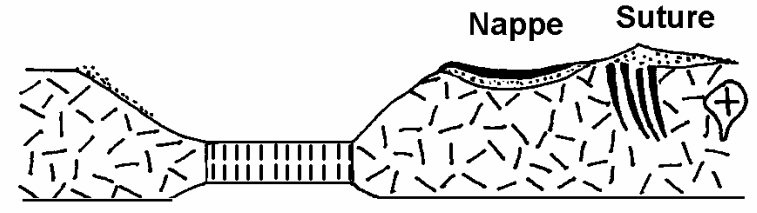

g

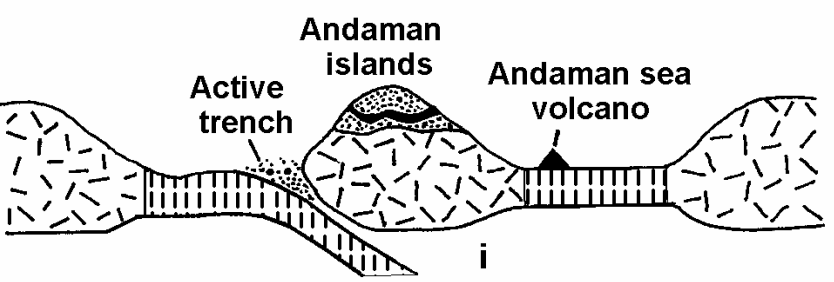

FIGURE 1. Schematic diagram showing successively closed oceanic basins relative to Indian and Sino-Burmese continents 